\title{
THE VISITING NURSE DEPARTMENT
}

\author{
; $7+4$ \\ IN OHARGE OF \\ HARRIET FULMER
}

THE problem of bringing skilled nursing care to the great middle class and the wage earner of moderate means, is still ringing in our ears. We discuss the matter at every nurses' gathering, large and small, and within our own ranks it is still unsettled. I believe firmly that the matter will be adjusted when visiting nurse organizations can be induced to create a separate pay department (perhaps self-supporting), just as hospitals have pay beds to meet the needs of small wage earners. While the average visiting nurse organization is maintained as a charity, I think it is a great mistake to dwell on this phase of the work and thus deprive many a worthy case of skilled care, because they can pay something, and yet are not willing to become an object of charity. If the nurse were employed as a regular member of the association, she could be required to have the same standard, and be directly under the control of the association. She would receive the regular salary the year round, and the patrons would be under financial obligation to the association only. Most visiting nurse associations liave a high standard for their workers, so that the chance of the working man getting inferior service from a cheap nurse supplied by a general registry would be obviated. Many a good nurse cannot take the cases in the homes of these working people for a reduced rate, because she cannot afford to do it. With an assured salary this objection is overcome and the middle-class family gets the skilled care it requires, just as the destitute poor man's family is receiving it to-day from these same organizations.

Boards of directors and nurses promoting visiting nurse work would do well to consider the nursing of the middle classes as one of their chief duties and obligations, just as hospital boards provide for the maintenance of beds where people may pay within their means, the income from these beds often being far below the actual cost of maintenance.

At the Conference of Visiting Nurses in Chicago in April last year, the adoption of a common seal or emblem for all visiting nurse organizations was discussed. The Cleveland organization submitted several designs at that time, one of which seemed to embody the real purpose and future of the work, and after giving every society the opportunity through 
the American Journal of Nursing of offering suggestions and designs, it has finally been decided by common consent of several larger organizations to adopt a common emblem giving every organization a right to use it, by paying the cost of the die. The design decided upon is the one submitted by the Cleveland association, this association being generous enough to donate $\$ 500$, the price of the design, then charging each society wishing to use it $\$ 50$, the actual cost for making the die, which will bear the name of the local society paying for this privilege. There is no doubt that the near future will see a National Visiting Nurse Society formed and the design will then be used as its national emblem. It is very important that the Cleveland committee know at once how many dies to order; therefore every organization is urged to communicate with the editor of this department at once regarding this matter. A picture and description of the design will be sent on application.

\section{THE JUBILEE CONGRESS OF DISTRICT NURSING}

THE work of district nursing originated in Liverpool. It was commenced by the late Mr. William Rathbone, Mr. Charles Langton and others, in 1859, and has since spread throughout the United Kingdom, and to many other countries. In commemoration of the jubilee of this important event, it is intended to hold a congress in Liverpool, to which will be invited delegates from all district nursing associations throughout Great Britain, Ireland, the Continent of Europe, the United States of America, and the Colonies; also representatives of medical authorities and of hospitals, with others interested in social work among the poor.

The congress will meet in Liverpool, England, on the 12th, 13th, and 14th of May, under the special patronage of Her Majesty Queen Alexandra. A provisional schedule of arrangements follows.

May 12. 3-5 P.M. Opening of the congress; reception at the Town Hall by the Lord Mayor. 8 P.M. Inaugural public meeting.

May 13. 10 A.M. to 3.30 P.M. Subjects: History of District Nursing in England and Other Countries; Importance of District Nursing as a Factor in Social Work; Maternity Work in Connection with District Nursing; Co-operation with Boards of Guardians, Charity Organizations, etc.

May 14. Morning: School Nursing in Connection with District Work. The District Nurses, Training, Inspection, etc. Future Developments and Valedictory. Afternoon: Reception on board an Atlantic liner.

Several nurses from America are going over and any visiting nurses wishing to go in a special party will please communicate with Miss Fulmer. 
The rapid growth of district or visiting nursing work in the United States is very strikingly shown by the figures contained in Miss Waters's forthcoming book; in June, 1905, there were 171 visiting nurse associations and 446 nurses; in December, 1908, 448 associations and 1256 nurses. In 1905, 34 new associations were formed; in 1906, 43; in 1907,51 , and in 1908, 100. Miss Waters's book will also give a full account of all the social service work of nurses and the auspices under which it is being done.

The Antituberculosis Society of Houghton, Michigan, is in need of a visiting nurse with social training and ability to organize the work. A good salary will be paid to a competent person.

"ALI children put under probation by court order should be given (they now are in Chicago) a thorough medical examination, and it should be a part of the duty of the officer in co-operation with parents, visiting nurses, hospitals, and sometimes the best specialists in the city, to see that all physical defects are treated. The number of delinquent children who need medical care is abnormally high, and the probation officer who fails to get medical advice about the children in her care fails to do what she should do for the child."-Henry W. ThURston, in Charities.

The Commissioner of Indian Affairs writes, of tuberculosis among Indians, in The Native American, as follows:

"The office is confronted by the urgent necessity of doing more than has ever been done before in the way' of protecting the Indians against the ravages of the disease, not only for their own sakes, but because the infected Indian community becomes a peril to every white community near it. It is, of course, almost hopcless to try to change the ways of the old-fashioned Indians past a certain point. What can be done in that line will probably be done through the work of the agency and school physicians, who sevcral months ago were constituted health officers with large authority to direct and control the sanitary conditions on their respective reservations. For the younger generation, and for such members of the older generations as may, here and therc, be disposed to takc advantage of them, I have established and am continually authorizing the establishment of sanitarium camps, where the inmates can fairly live in the open air, be constantly under the eye of the physician, have their dict, clothing, etc., carefully regulated, and be subject to the most stringent regulations as to those matters which make for cleanliness of the person and surroundings, and affect the spread of infection." 